\title{
Open Innovation for Business-IT Academic Institution: Case of Oman
}

\author{
Dr. Maria Teresa Matriano \\ Assistant Professor, Department of Management Studies \\ Middle East College, Muscat, Oman
}

\begin{abstract}
Oman's economic activities are often centered on oil production and export with very limited focus given towards enhancing its private sector. The more traditional approach to business also inhibits the growth of some of the business organizations in the country because of the lack of attention to innovation. However, finding new opportunities through innovation can be also made possible through a mutually beneficial partnership with the academic sector through open innovation. The cooperation between the business IT academic institutions and the business sector is key in achieving success in innovation on an economic level. The shared knowledge between the two sectors is crucial in ensuring that new ideas and technologies are delivered to the end consumers in a form of an innovative product of services. In the case of Oman, several challenges are facing both the academic and the private sector in terms of establishing an open innovation partnership. In this discussion, the concept of open innovation for business IT will be highlighted with emphasis given to the current state of open innovation partnerships in Oman. In addition, the discussion will also explore the advantages of open innovation in business IT in terms of fostering innovation through research and development.
\end{abstract}

Keywords: Open Innovation, Business IT, Institutional Partnership, Research and Development

\section{INTRODUCTION}

Open innovation initiatives lead companies to take partnerships with educational institutions most notably universities in the objective of establishing a partnership beyond their usual research development department. The role of educational institutions in an open innovation is to discover new ideas and the companies to have access to the pools of knowledge emerging from the partnership (Spender and Corvello, 2015). One of the major benefits of an open innovation is that companies will have an opportunity to get their hands on the new discoveries and utilize them to create new products or improve their existing ones. The same can be observed in an open innovation for business IT among academic institutions. When referring to business IT, it involves technologies or new techniques developed by academic institutions for the purpose of improving business processes. In this discussion, the importance of open innovation for business IT academic institutions will be examined with emphasis given to the role of the private sector and the educational sector partnership in the open innovation objectives. In addition, the current status of academic institutions in Oman in terms of engaging in open innovation in the field of business IT will be explored.

A large number of literatures that focuses on examining the openness of universties and firms in engaging in innovation can be a good resource, which encompasses the direction of this discussion. Examining the subject at hand requires a review of the existing literatures both primary and secondary particularly the literatures pertaining to the concept of open innovation among business IT academic institutions and the business sector. In addition, these 
concepts to be explored will be applied to the analysis of the current business IT academic institutions and private sector partnership in Oman. The country is largely reliant in its oil industry for the longest time and it's about time that it gives attention to enhancing the opportunities for growth of its small private sector through innovation in partnership with the academic institutions in the country. Part of Oman's initiative for 2020 is to raise it global competitiveness through innovation, which begins with an open partnership with both the educational and business sectors. One of the major focuses of such partnership is the development of innovations within the business IT academic institutions, which is essential in discovering new technologies and strategies in business.

\section{OPEN INNOVATION FOR BUSINESS-IT ACADEMIC INSTITUTIONS}

The term open innovation is a concept that falls in the gap between the academe and the business (Chesbrough, 2011). There are a lot of opportunities for companies to profit from open innovation apart from the savings derived from R\&D costs and resources. This is because the fruit of the partnership with the academe goes straight to the hands of firms, which in return becomes a new product or services that hauls in more profit for the company. According to the study by Becker and Eube (2018), companies are important economic generators given their capacity to provide jobs and are operating in a global defined by competition. This is where the role of knowledge and its circulation becomes crucial for survival for many business organizations. Meanwhile, educational institutions assumes the role of knowledge providers in which the economic centered view of this role demonstrates the concept of open innovation. Empirical studies describes the important benefits obtained by businesses from public knowledge produced by the academe in terms of leverage effect. Cockburn and Henderson (2000) argues that access to university knowledge enhances the efficiency rate and effectiveness of innovation outcomes. In this sense, that the business sector is trying to establish a deeper relationship with the academic institutions considering the fruitful outcome that can be achieved in terms of innovation.

Although academic institutions and businesses are in diametrical opposites in terms of how they utilize information apart from the difference in aims, objectives, and structures, there exists a relationship that is deeper than ever before (Rayna and Striukova, 2015). On the other hand the encompassing benefit of open innovation is not only limited to the companies that the academic institutions are in partnership with. In the IT industry, the resulting product of the technology research by the academe enable IT companies to save on the cost of R\&D and the licensing of one another's software is shared with the larger number of end users (Chachoua, 2015). Considering that the knowledge provided and circulated from the academic institutions are considered more of a public knowledge, the drawbacks of patent disputes amongst the end users are reduced. This is because the innovation ideas emerging from the public knowledge is called an open source, hence, the exclusivity of the use of such knowledge is almost inapplicable (Vanhaverbeke et al., 2008). Meanwhile, the benefit that academic institutions derive from the open innovation partnership is the people transfer, which involves exchange of people from the academic institution to the firms since businesses provides employment opportunity for the institution's graduates (Roshani et al., 2015).

\section{OPEN INNOVATION COOPERATION IN OMAN}

It is apparent that open innovation partnership between the academic institutions and the business sector is crucial in the information exchange and circulation, which is key to fostering innovation. In the case of Oman, open innovation for business IT in the academic institutions is facing major obstacles because there is no strong engagement between the two sector when it comes to innovation partnerships (UNCTAD, 2014). Oman has well-developed academic institutions Sultan Qaboos University being the first public university in the country. The SQU 
along with other institutions such as The Higher College of Technology and Middle East College in Muscat houses a number of research centers for various academic focuses. There are number of institutions in Oman that offers academic programs for business and economic with integration of IT is offered in a separate institution. But according to the report by UNCTAD (2014), there was still lack of greater input from the firms in the country towards curricula design at universities and vocational schools.

One of the major areas for improvement among the business IT academes in Oman is to increase the students' right competencies that are business innovation-related particularly in the fields of communication and business research. Furthermore, Hasan (2015) stated that Oman is ranked $81^{\text {st }}$ among the global nations in terms of successful research although the country is ranked $8^{\text {th }}$ in the world in terms of the number of research carried out by a nation. This encompasses the measure of the quality of research produced by the knowledge institutions in the country because of the relatively inadequate support from the business sector. In addition, strong cooperation between universities and firms in Oman is needed on R\&D, innovation, and technology adaptation (UNCTAD, 2014). The observed limitations in the institutional partnership with firms in the country is a result of the industry perspective in which the focus of the research tends to be more academic than exhibiting practical applicability. Such characteristic of the current research trend in the academe encompasses a limitation on the potential cooperation with the business sector. In addition, a number of the public technology and research infrastructure has been established to focus mainly on fisheries and agriculture. Finally, open innovation in Oman is largely limited due to the relational perspective of the organizational leaders, which depends mainly on personal relationships instead of a more formal approach.

\section{CHALLENGES AT HAND}

For most organization, open innovation would encompass certain consideration towards developing the capacity to adapt to the changes brought by the cooperation with other organizations. It is apparent that open innovation for business IT requires a great deal of cooperation with the academic institutions. This involves managing people and resources with a level of information logistics applied to ensure that the exchange of knowledge is efficiently captured by both parties. The challenges for open innovation for developing business IT between the academe and the business sector in Oman includes sufficient strategies that will encourage creative methods teaching among academics (Bindah and Magd, 2015). In addition, Bindah and Magd (2015) pointed out that there is a very small business and entrepreneurship development in the country that involves partnership with the academic sector.

\section{DISCUSSION}

Economic experts strongly believe that innovation is the key to the future of countries such as Oman. After oil, the next important work for Oman is to strengthen its private sector, the SME sector, and promote innovation among these environments. On the other hand, achieving success in innovation requires giving attention to how knowledge and ideas were utilized and where they come from. Successful innovation requires expertise and information derived from research through R\&D. However, not all business organizations much more the SMEs would not be able to afford to invest in R\&D. One of the major benefits of open innovation is that the research activities are carried out by the academic institutions, which encompasses lesser cost for business organization. The same goes for SMEs and even larger corporations in Oman, engaging in an open innovation initiative will not only provide access to knowledge, but also enable smaller businesses to take part in the knowledge development process. Innovation in Oman is beginning to flourish given the urgency of diversifying the country's economic dependency from oil to SME and growing its private sector. 
On the other hand, ensuring a positive outlook for the private sector and SMEs in Oman would require looking into how innovation can be integrated into business. Surely the open innovation partnership with the academic sector would generate mutually beneficial outcome for business organizations in the country. However, innovating business would mean partnering with academic institutions that specializes in business IT. Oman has several companies in the fishing industry and the integration of business IT to develop innovation in partnership with the academic sector in the country is to create an advanced marine biotechnology for the fishing industry (Al-Belushi et al., 2015). One example of companies in Oman that exhibits progress through open innovation in business IT is Sea Pride LLC, which is a company that began with traditional fish capture activities and now specializes in fish meal and fish oil. The progression from the traditional fishing business into an innovative producer of other fish products was a result of open innovation partnerships with research organizations in both the public and private sector. This example encompasses the potential of establishing a strong relationship with business IT academic institutions when innovating.

Considering the role of business IT academic institutions in the concept of open innovation, it is important for Oman to consider alleviating the obstacles in successfully establishing a longlasting relationship between the academic and the business sector. According to the report by the TRC (2017), a national system for open innovation is necessary for the institutional and social integration of new innovations in the country. This includes integration of innovation policies, research and development, knowledge transfer, and infrastructure. There are several educational institutions in Oman that can accommodate business IT innovations such as Middle East College, Dhofar University, Sultan Qaboos University, Muscat College and among others. Equipping the current curricula in the aforementioned institutions engaged in business IT with the skills required to success in the knowledge-based economy would enable open innovation to be a more integral part of the growth of the business sector in the country. Allowing the educational institutions to enhance its business IT focused academic programs would contribute to the increase in the number quality research and development activities wherein the private sector can participate through open innovation.

\section{CONCLUSION}

Open innovation is only possible if both the business and the academic sector will form a collaborative effort in ensuring that the inflows and outflows of knowledge are utilized to accelerate the country's overall economy. Traditional research and development approach encompasses a barrier to entry by competitors and the lack knowledge sharing within the business sector and the academic sector impedes innovation as a whole. In the case of Oman, open innovation for business IT cannot be considered as consistently successful because of several factors. For one, the academic sector in Oman is not fully equipped in terms of curriculum programs that relates to business IT and research development. One of the causes of the inadequacies is the traditional approach to academic structure that does not compliment well with the requirements of open innovation. In addition, the country has a very small private sector that has a varying perspective over the concept of shared knowledge. However, establishing an open innovation between the education and the private sector can be enhanced through policy reforms and both sectors to embrace change in order to innovate together.

\section{References}

Al-Belushi, K., Stead, S. and Burgess, J. (2015). The development of marine biotechnology in Oman: Potential for capacity building through open innovation. Marine Policy, 57, pp.147-157.

Ashrafi, R. and Murtaza, M. (2008). Use and Impact of ICT on SMEs in Oman. The Electronic Journal Information Systems Evaluation, [online] 11(3), pp.125 - 138. Available at:

http://www.ejise.com/issue/download.html?idArticle=727 [Accessed 19 Jun. 2018]. 
Becker, B. and Eube, C. (2018). Open innovation concept: integrating universities and business in digital age. Journal of Open Innovation: Technology, Market, and Complexity, 4(1).

Bindah, E. and Magd, H. (2016). Teaching Entrepreneurship in Oman: Successful Approaches. Procedia - Social and Behavioral Sciences, 219, pp.140-144.

Chachoua, E. (2015). The benefits of open innovation. [online] World Economic Forum. Available at: https://www.weforum.org/agenda/2015/02/the-benefits-of-open-innovation/ [Accessed 19 Jun. 2018].

Chesbrough, H. (2011). Everything You Need to Know About Open Innovation. [online] Forbes.com. Available at: https://www.forbes.com/sites/henrychesbrough/2011/03/21/everything-you-need-to-know-about-openinnovation/\#5e20277d75f4 [Accessed 19 Jun. 2018].

Cockburn, I. and Henderson, R. (2000). Publicly Funded Science and the Productivity of the Pharmaceutical Industry. Innovation Policy and the Economy, 1, pp.1-34.

Hasan, S. (2016). Plan to make Oman a hub for innovation in healthcare. [online] Times of Oman. Available at: http://timesofoman.com/article/92590 [Accessed 19 Jun. 2018].

Oxford Business Group (n.d.). Oman's ICT use to expand. [online] Oxford Business Group. Available at: https://oxfordbusinessgroup.com/overview/strategic-thinking-increased-demand-connectivity-andgovernment-led-initiatives-combine-expand-ict [Accessed 19 Jun. 2018].

Roshani, M., Lehoux, N. and Frayret, J. (2015). University-Industry Collaborations and Open Innovation: An Integrated Methodology for Mutually Beneficial Relationship. Report. [online] CIRRELT-2015-22: CIRRELT. Available at: https://www.cirrelt.ca/DocumentsTravail/CIRRELT-2015-22.pdf [Accessed 19 Jun. 2018].

Spender, J., Corvello, V., Grimaldi, M. and Rippa, P. (2017). Startups and open innovation: a review of the literature. European Journal of Innovation Management, 20(1), pp.4-30.

Striukova, L. and Rayna, T. (2015). University-industry knowledge exchange. European Journal of Innovation Management, 18(4), pp.471-492.

TRC (2017). The National Innovation Strategy. Insights Scientific. [online] Qaboos: The Research Council. Available at: https://www.trc.gov.om/trcweb/sites/default/files/2017-08/scientific\%20insights.pdf [Accessed 19 Jun. 2018].

UNCTAD (2014). Oman. Science, Technology and Innovation Policy Review. [online] Geneva: United Nations. Available at: http://unctad.org/en/PublicationsLibrary/dtlstict2014d1_en.pdf [Accessed 19 Jun. 2018].

Vanhaverbeke, W., Van de Vrande, V. and Chesbrough, H. (2008). Understanding the Advantages of Open Innovation Practices in Corporate Venturing in Terms of Real Options. Creativity and Innovation Management, 17(4), pp.251-258. 